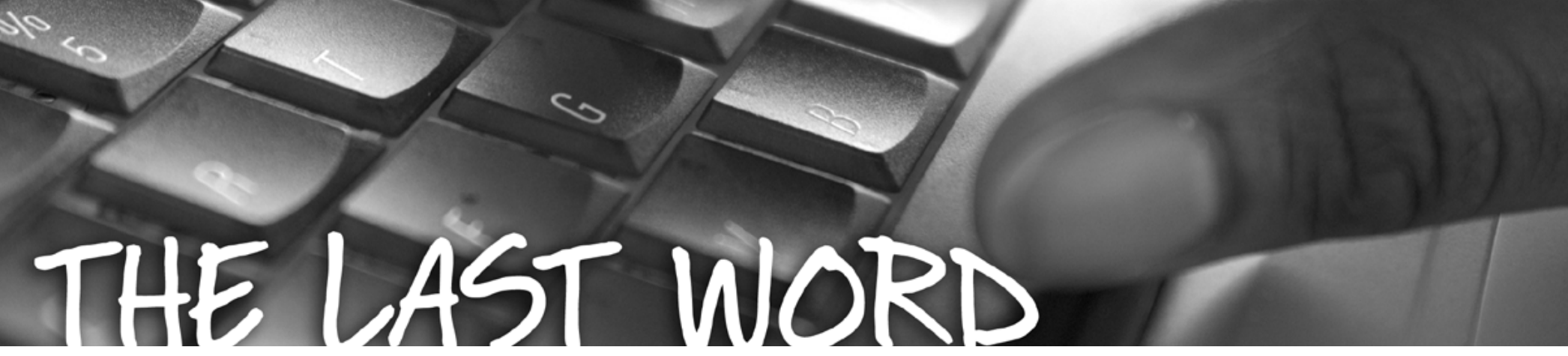

\title{
Pitching Poetry
}

\section{Laura Purdie Salas}

Libraries are a place to walk on the wild side, to try something new. As a reader, when I walk into a library, I feel like an adventurer setting off on a grand expedition of discovery. As a writer, I love it when librarians guide young adventurers off the well-traveled highway and down the small, shady path toward poetry.
Poetry gives so much to readers! It makes them feel something, and it connects readers to both the world and to each other. Its powerful, concentrated language builds better readers and writers, and, frankly, it's just a whole lot of fun. That's why poetry comes first, both in my heart and in my Genre Chant poem. Who can you lead down the poetry path today?

\section{The Genre Chant}

Ready to read?

What mood are you in?

Limitless choices!

Where to begin?

poetry

(lines to crack world's heart)

picture books

(words, swirled with art)

informational

(factual-please, tell me more)

realistic fiction

(it's the girl next door)

fantastic fiction

(weird worlds-wow!) contemporary fiction

(it's happening now)

biography

(life of one human being)

modern fantasy

(teens and the ghosts they are seeing)

historical fiction

(about a time gone by)

science fiction

(it's possible pi-in-the-sky)

folklore

(passed down age upon age)

They all wait for you.

Turn the page. $\measuredangle$.

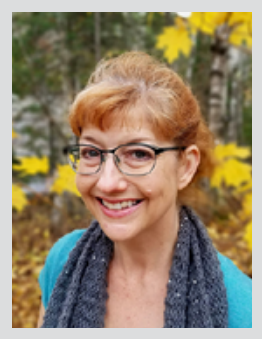

Laura Purdie Salas is a children's writer, poet, and visiting author. Her many poetry and nonfiction books include If You Were the Moon, Water Can Be..., and BookSpeak! A printable mini-poster of The Genre Chant is available at http://tinyurl.com/y8geb923, and you can visit the author at www.laurasalas.com.

Got a great, lighthearted essay? A funny story about children and libraries? Books and babies? Pets and picture books?

A not-so-serious look at the world of children's librarianship? Send your Last Word to Sharon Verbeten at CALeditor@yahoo.com. 